\title{
The Current Situation and Problems of Zhima Credit
}

\author{
Min Ke ${ }^{\mathrm{a}}$, Shengjie Chen ${ }^{\mathrm{b}}$, Nianci Cai ${ }^{\mathrm{c}}$, Li Zhang ${ }^{\mathrm{d} \text {,* }}$ \\ School of Finance and Accounting, Fuzhou University of International Studies and Trade, Changle, China, \\ a1151328550@qq.com, b794228674@qq.com, ${ }^{\text {c } 1056970543 @ q q . c o m, ~}{ }^{\mathrm{d}}$ 285889359@qq.com
}

Keywords: Internet finance, Big-data credit reporting, Zhima Credit

\begin{abstract}
Credit reporting agencies are regarded as the core force in the operation of the financial system. With the development of the Internet technology and the arrival of the big data era, the credit investigation industry has been well integrated with big data, which has solved some difficulties faced by the traditional credit investigation industry, and it also has its own advantages. However,there are still some problems in data security, perfection and authenticity. This article will take Zhima Credit as an example to analyse the existing problems of Zhima credit based on the development status of third-party credit investigation in the context of Internet finance, and put forward corresponding development proposals.It is hoped that this article will help personal credit investigation to function in Internet finance better.
\end{abstract}

\section{Introduction}

With the development of big data technology, it has penetrated into various industries and fields, and triggered extensive social changes. In the big data era, credit investigation industry takes data collection as its core. Recently, China's Internet finance has developed by leaps and bounds. As an important means to prevent risks, Internet credit has been paid attention to by all parties. Comparing with traditional personal credit, even if the Internet credit has a large inventory of data, there will be a lack of credit risk assessment theory. Data authenticity, availability and responsiveness are also worth considering. If these objective problems are ignored, it can also cause immeasurable losses.

Market economy's core is finance, and finance's cornerstone is credit. To obtain the healthy development of the industry, it is necessary to have an impeccable credit system. Therefore, to promote the steady development of the Internet credit industry, the state should pay attention to the existing problems, and take measures to improve the financial market as soon as possible. The main purpose of this article is to take "Zhima Credit" as an example, analyze its development status, integrate Internet credit industry's problems, and put forward suggestions for improvement.

\section{Summary of Big Data Credit Reporting}

\subsection{Definition of Big Data Credit Reporting}

In the field of financial risk control, big data refers to full data and user behaviour data. At present, data that is highly related to customer's credit status are used for scientific risk control. IDC, the research institute, summarized the characteristics of big data into $4 \mathrm{~V}$ : massive data size (Volume), rapid data flow and dynamic data architecture (Velocity), diverse data types (Variety), and huge data value (Value) ${ }^{1}$. Credit investigation is a kind of activity that collects, sorts out, stores and processes information subjects according to law, and provides services such as credit report, credit assessment and credit information consultation to help clients to judge, control credit risks and conduct credit management.

We can conclude that data credit refers to risk assessment by using data analysis and model. According to the assessment score, repayment ability, repayment willingness and fraud risk of the payer can be predicted. The development of big data credit is the organic combination of data collection, technology research, method infiltration and system guarantee. The foundation of its development is the collection of data. 


\subsection{Comparison between Big Data Credit and Traditional Credit Collection}

China's current personal credit industry is divided into public credit system and market credit system, with public credit system as the dominant, the core of which is the central bank's financial credit information base database, the credit centre of the institutions directly under the central bank is responsible for the operation and information processing. Nowadays, it has been mature and stable. As of July 2017, it covers 932 million natural persons, of which 458 million have credit records. Since its operation, it has provided 4.521 billion personal credit report inquiries. ${ }^{2}$

However, due to the problems of weak awareness, late start and backward technology in early China, there were some inherent shortcomings, such as the symmetry of information, the perfection of data and so on. The emergence of big data credit effectively complements the traditional credit industry's limitations, and in terms of its future development, cost and the convenience of obtaining data, it also gives the modern financial system a great reason to support the development. So the traditional credit provided great significance for the industry's development.

\section{Development Status of Zhima Credit}

\subsection{Basic Introduction of Zhima Credit}

On January 5, 2015, the People's Bank of China issued 《The Notice on Preparatory Work for Personal Credit Reporting 》. Eight organizations are required to prepare for personal credit reporting, included Zhima Credit Management Limited. Then, Zhima first opened Zhima credit score at the end of January, intuitively presenting the user's credit level, and started the prelude of Internet financial credit investigation. ${ }^{3}$

Zhima Credit is the third party personal credit agency designed with the support of large data. Supported by cloud technology, the credit situation can be obtained by analysing the user's consumption records. There are three main reasons for promoting its development.: First, the reform of credit market; Second, the development of Internet technology; Third, the increasing importance of personal credit.

\subsection{Operation Mode of Zhima Credit}

Zhima Credit has data sources and collection processes that rely on the support and processing of large data technologies and cloud technologies. In terms of core products and credit scoring model, Zhima Credit is based on the FICO score of the United States. The scoring span is between 300 and 950. The higher the score means the better the credit. ${ }^{4}$ The scoring results consist of five dimensions: behaviour preference, performance ability, identity traits, relationship, and credit history. The scores of different dimensions will affect the final result.

\subsection{Development Status of Zhima Credit}

So what does Zhima Credit offer to Internet Finance? Firstly, reduce the loan or the bad debt rate of instalment repayment. Using big data to collect credit records, conduct credit evaluation and reduce credit risk. The two is to expand the market input and receiving volume of the upper and lower two parties. Companies docked with the personal credit system have the strength to compete with traditional banks, and are more secure in obtaining better borrowers, quality college students or customers. In 2017, Zhima Credit cooperated with China Construction Bank to establish a new online and offline parallel business model, which greatly improved its credit system. While gaining a lot of trust, Zhima Credit must ensure its quality; otherwise it will cause an immeasurable blow to the Internet financial market.

\section{Problems in Zhima Credit Development}

\subsection{User Information Security}

While enjoying the convenience, users will inevitably worry about the personal privacy and 
validity of data collection. According to the 《China Netizens Rights and Interests Protection Survey Report 2016》, 84\% of the Netizens feel the negative impact of personal information leakage, $54 \%$ of the netizens think that personal information leakage is serious, $21 \%$ of them think it is very serious. ${ }^{5}$ Several industry analysts pointed out that there are many links in personal information acquisition, storage and utilization, and offline and online dissemination is hidden and complex, the high cost of tracing back to the source, the difficulty of discovering and investigating, the punishment and the compensatory power make the sale and illegal use of information in the BLACK-GREY industrial chain have huge speculative space .

\subsection{The Dimension of Data Acquisition Is Not Comprehensive Enough}

Zhima Credit is based on Internet data rating analysis, data is the core of its operation. Only by satisfying the diversity, novelty and comprehensiveness of data can it sustain its steady development. On the one hand, with the development of network technology, the frequency of unstructured data usage is greatly increased, if Zhima Credit progresses can't keep up with the pace of updating, data shortage will inevitably arise. On the other hand, the biggest advantage of Zhima Credit comes from the data support provided by Alibaba, which is a large data group. However, to a certain extent, when users basically cover the public, it is difficult to update the database. At this point, the development of Zhima Credit will be limited.

\subsection{Data Quality Problem}

Zhima Credit as a credit rating platform, the authoritativeness of its data, and the credibility of the results of the evaluation is bound to be the most concerned issues. In the Zhima Credit user survey found that the Zhima Credit score higher are mostly users with higher frequency. It can't exclude individual illegal users in order to improve ratings for manipulation. Additionally, the virtuality of Internet ports also threatens the authenticity of data. Its data processing and scoring cannot be effectively monitored, which makes the reliability and authenticity greatly reduced.

\section{Make Recommendations for the Existing Problems}

\subsection{Strengthening the Privacy Protection of Internet Financial Credit Reporting}

It is a cliché to urge the relevant government departments to strengthen legislation. In the formulation of regulatory systems, it must to suit the remedy to the case. The problem of government legislation needs to be solved is a dilemma between protecting business and user privacy. Credit agencies are required to improve the transparency of credit evaluation and the security of information storage, and to clarify the complaint mechanism when user privacy is violated. Credit reporting industries such as Zhima Credit should implement the privacy protection system and use industry ethics to restrain them.

\subsection{Broaden User Access to Expand the Scope of Basic Data}

To solve the problem of data islands, one is to build a one-to-one identification system on the network port such as ID card number. It will broaden the access to user information, and can be regulated by the government to avoid monopoly and abuse of data. Secondly, absorb the central bank personal credit information database resources, promote the docking of online and offline credit reporting system, and break the information isolated situation.

\subsection{Strengthen User Information Verification and Inspection to Ensure Data Quality}

To ensure the quality of data, there are two parts, collection and processing. When collecting data, it requires credit agencies to be fair and accurate in selecting high-quality data. In addition, we should speed up the development of data credit technology, in-depth study of data processing reserve, especially the unstructured data's processing. Establish and improve government restraint and industry consciousness, form a good market. Besides, we should establish a disciplinary mechanism for breach of faith to prevent malicious scoring behaviour. A "list of dishonest persons" 
should be established. Once it is disclosed, it will restrict the use of Internet financial ports and increase the cost of crime. Enterprises must also pay attention to the training of high-level personnel and do a good job of daily data security maintenance and the authenticity of information collection.

\section{Summary}

Based on the development of third-party credit reporting under the background of Internet finance, this paper analyses the problems of Zhima Credit, and puts forward some development suggestions. Zhima Credit is an inheritance and development the transformation of the traditional credit industry in Internet finance. However, because China has been using the Internet for a relatively short period of time in the field of large data credit investigation, it cannot be compared with foreign developed countries for the time being. The problems are inevitable in the development process. Zhima Credit is also a good example of China's Internet finance is bound to flourish in the big data era. It brings a qualitative leap to the traditional credit industry. The existing problems and solutions are expected to provide reference for the development of large data credit.

\section{Acknowledgements}

This project is funded by the Fujian Undergraduate Training Programs for Innovation and Entrepreneurship. Item Number: 201713762022.

\section{References}

[1] Lin Pingi, thinking of speeding up the development of China's credit market under the background of big data, Southern finance, the 459 phase.

[2] Mao Beibei, the credit investigation practice of sesame credit and its enlightenment to China's credit investigation system, Science and technology research rural staff, [J], 11400

[3] Lv Na, Some thoughts on personal credit investigation of Internet finance -- take sesame credit as an example, [J], NO.11, 2017

[4] Source of data: the people's Bank of China credit reporting centre. Personal credit reporting system running monthly, 2017 (7)

[5] Wang Xii, Alipay's bills are in turmoil. What's wrong with Zhima Credit? China times, January 8, 2018 edition 019. 